\title{
Allogeneic umbilical cord-derived mesenchymal stem cell transplantation for treating chronic obstructive pulmonary disease: a pilot clinical study
}

Phuong Le Thi Bich ${ }^{1}$, Ha Nguyen Thi ${ }^{1}$, Hoang Dang Ngo Chau' ${ }^{1}$, Tien Phan Van ${ }^{1}$, Quyet Do ${ }^{2}$, Hung Dong Khac ${ }^{2}$, Dong Le Van², Luc Nguyen Huy ${ }^{2}$, Khan Mai Cong², Thang Ta Ba², Trung Do Minh'², Ngoc Vu Bich³,

Nhat Truong $\mathrm{Chau}^{3}$ and Phuc Van Pham ${ }^{3,4^{*}}$ (i)

\begin{abstract}
Introduction: Chronic obstructive pulmonary disease (COPD) is the third leading cause of death worldwide. COPD results from chronic inflammation of the lungs. Current treatments, including physical and chemical therapies, provide limited results. Stem cells, particularly mesenchymal stem cells (MSCs), are used to treat COPD. Here, we evaluated the safety and efficacy of umbilical cord-derived (UC)-MSCs for treating COPD.

Methods: Twenty patients were enrolled, 9 at stage $C$ and 11 at stage D per the Global Initiative for Obstructive Lung Disease (GOLD) classification. Patients were infused with $10^{6}$ cells $/ \mathrm{kg}$ of expanded allogeneic UC-MSCs. All patients were followed for 6 months after the first infusion. The treatment end-point included a comprehensive safety evaluation, pulmonary function testing (PFT), and quality-of-life indicators including questionnaires, the 6-min walk test (6MWT), and systemic inflammation assessments. All patients completed the full infusion and 6-month follow-up.

Results: No infusion-related toxicities, deaths, or severe adverse events occurred that were deemed related to UCMSC administration. The UC-MSC-transplanted patients showed a significantly reduced Modified Medical Research Council score, COPD assessment test, and number of exacerbations. However, the forced expiratory volume in $1 \mathrm{~s}$, C-reactive protein, and $6 \mathrm{MWT}$ values were nonsignificantly reduced after treatment (1, 3, and 6 months) compared with those before the treatment.
\end{abstract}

Conclusion: Systemic UC-MSC administration appears to be safe in patients with moderate-to-severe COPD, can significantly improve their quality of life, and provides a basis for subsequent cell therapy investigations.

Trial registration: ISRCTN, ISRCTN70443938. Registered 06 July 2019

Keywords: Umbilical cord-derived mesenchymal stem cells, Mesenchymal stem cells, COPD, Chronic obstructive pulmonary disease

\footnotetext{
* Correspondence: pvphuc@hcmuns.edu.vn; phucpham@sci.edu.vn

${ }^{3}$ Stem Cell Institute, VNUHCM University of Science, Ho Chi Minh City, Viet Nam

${ }^{4}$ Laboratory of Stem Cell Research and Application, VNUHCM University of

Science, Ho Chi Minh City, Viet Nam

Full list of author information is available at the end of the article
}

(c) The Author(s). 2020 Open Access This article is distributed under the terms of the Creative Commons Attribution 4.0 International License (http://creativecommons.org/licenses/by/4.0/), which permits unrestricted use, distribution, and reproduction in any medium, provided you give appropriate credit to the original author(s) and the source, provide a link to the Creative Commons license, and indicate if changes were made. The Creative Commons Public Domain Dedication waiver (http://creativecommons.org/publicdomain/zero/1.0/) applies to the data made available in this article, unless otherwise stated. 


\section{Introduction}

Chronic obstructive pulmonary disease (COPD) was the third leading cause of death in the USA in 2005 (https:// www.cdc.gov/copd/basics-about.html). According to the World Health Organization (WHO) estimates, 65 million people worldwide have moderate-to-severe COPD. In 2005, more than 3 million people died of COPD, accounting for $5 \%$ of all deaths that year. Numbers of COPD patients are expected to increase by more than $30 \%$ in the next 10 years (https://www.cdc.gov/copd/basics-about.html), and COPD is expected to be the third leading cause of death worldwide in 2020. COPD is treated with medications, including bronchodilators, inhaled steroids, oral steroids, phosphodiesterase- 4 inhibitors, theophylline, and antibiotics; lung therapies, such as oxygen therapy and pulmonary rehabilitation programs; and surgeries, including lung-volume reduction surgery, lung transplantation, and bullectomy. However, these therapies have limited efficacy and severe adverse effects [1-3]. Stem cell therapy, especially with mesenchymal stem cells (MSCs), is a promising therapy for treating various diseases, including inflammation and autoimmune diseases [4-6].

MSCs are adult stem cells often used to treat diseases such as graft-versus-host disease (GVHD) [5], osteoarthritis [7], autoimmune diseases [8], and liver cirrhosis [9]. Several off-the-shelf mesenchymal stem-cell therapies have been approved as drugs for some diseases. These include Prochymal for GVHD (in Canada) [10], Cartistem for knee osteoarthritis (in South Korea) [11, 12], and Temcell HS for GVHD (in Japan) [13]. MSCs can be derived from different sources such as bone marrow [14-16], adipose tissue [17-20], peripheral blood [21, 22], umbilical cord blood [23, 24], and umbilical cord tissue [25-27]. MSCs have three beneficial therapeutic mechanisms. First, MSCs can modulate the host immune system by inhibiting some immune cells and stimulating others [28-30], thus participating in regulating the immune system. This is the main mechanism of the MSCs used to treat GVHD, autoimmune diseases and inflammatory diseases [31-36]. Recent studies have shown that MSCs can directly interact with immune cells and secrete cytokines or interleukins to regulate host immune cells [37-40]. The second mechanism relates to the MSC secretome. MSCs can produce a wide variety of cell signaling cytokines and growth factors targeting endogenous stem cell self-renewal and migration [41-44] and can trigger host stem cells to self-renew and differentiate to heal an injury. Finally, MSCs can home and differentiate after transplantation [45-47]. In some cases, particularly, in autologous transplantation, MSCs can home and reestablish stem cell niches in the host. These MSCs can differentiate into functional cells that participate in tissue regeneration.
Moreover, MSCs are of interest for therapies using adult stem cells because they can be used in allogeneic transplantation cases that are not HLA-matched between stem cells and recipients. MSCs express low levels of human leukocyte (HLA) class I [48, 49]. They also do not express HLA class II or costimulatory molecules, including CD40, CD80, and CD86, which are essential for $\mathrm{T}$ cell immune responses $[48,49]$.

MSCs have been applied in both autologous and allogeneic transplantations in animals and humans to treat diseases, including COPD. The first allogeneic MSC transplantation was the application of prochymal to treat COPD. Prochymal is the first allogeneic off-the-shelf stem cell treatment produced from human bone marrow. This product was approved as a drug in Canada in 2012 to treat GVHD. A report from Osiris Therapeutics showed that prochymal transplantation provided some benefits without adverse effects in 62 COPD patients but did not improve their quality of life or lung function [50]. Other studies have used MSCs derived from bone marrow (BM) or adipose tissue to treat COPD [51-53]; however, most studies showed limited efficacy [51-53]. The failure of these three clinical trials revealed some issues relating to MSC transplantation for COPD. The first issue may involve the use of frozen MSCs. In the first clinical trial (NCT00683722), frozen BM-MSCs were thawed and directly infused into patients immediately after thawing in frozen bags [50]. The off-the-shelf BM-MSCs were produced on an industrial scale as stem-cell drugs. Although this product enables easy and convenient transplantation, a recent report showed that newly thawed MSCs lose part of their immunomodulatory capacity [54]. Similarly, in the second clinical trial (NCT01306513), the newly thawed cells were also directly used to treat patients but with low efficacy [51, 52]. Thus, fresh cultured BM-MSCs should be used instead of newly thawed BM-MSCs. However, a newer clinical trial (NCT01110252) used fresh cultured BM-MSCs but yielded no improvement in clinical outcomes [53]. Thus, autologous BM-MSCs may be unsuitable for treating COPD. BM-MSCs are usually isolated from adult patients, and BM-MSCs from aging patients can function abnormally compared with MSCs derived from younger tissues. In animals, BM-MSCs from aged animals have shorter telomere lengths, reduced differentiation capacity, impaired proliferation, and decreased paracrine factor production compared with those from younger animals [55-57]. In mouse models, BM-MSCs from aged mice showed downregulated cytokine and chemokine receptor expression. These BM-MSCs were also less mobilized to lung injury compared with BM-MSCs derived from younger mice [58]. Human BM-MSCs from aged patients highly express senescence-related genes, shorter telomere length, low proliferation and low differentiation 
capacity [59]. In summary, BM-MSCs appear unsuitable for COPD treatment.

In contrast to BM-MSCs, umbilical cord-derived MSCs (UC-MSCs) exhibit strong modulation capacity, and under the same conditions, we found that UCMSCs more strongly inhibited allogeneic lymphocytes than did BM-MSCs or adipose tissue-derived mesenchymal stem cells [60-62]. UC-MSCs also have higher proliferation rates, are more primitive than are BM-MSCs $[63,64]$, and exhibit better potential to differentiate into other cells [63-66]. Thus, we hypothesize that UCMSCs are suitable MSC sources for COPD treatment. Therefore, this study evaluated the efficacy and safety of using expanded allogeneic MSCs from human umbilical cord tissue to treat COPD.

\section{Materials and methods}

\section{Study design and oversight}

This was a pilot clinical trial, without a control group. The institutional review board (scientific and ethical committee) of Van Hanh General Hospital (Ho Chi Minh City, Viet Nam, no. 084/2017/QD-NCKH) and Vietnam Military Academy 103 (Hanoi, Vietnam) approved the study, and all participants provided written informed consent. The study was conducted in accordance with the amended Declaration of Helsinki.

\section{Patient selection}

Eligible patients were aged 40-80 years with moderateto-severe COPD at stage $\mathrm{C}$ or D per the Global Initiative for Chronic Lung Disease (GOLD), had a smoking history of $>10$ pack-years, a postbronchodilator forced expiratory volume in $1 \mathrm{~s}\left(\mathrm{FEV}_{1}\right) /$ forced volume capacity (FVC) ratio $<70 \%$, and a postbronchodilator $\mathrm{FEV}_{1}$ between 30 and $70 \%$ of the predicted value (Fig. 1).

The inclusion criteria were as follows:

(1) Diagnosed with COPD stage C or D in accordance with GOLD 2016;

(2) Aged 40-80 years;

(3) Understood and agreed to the written consent form.

The exclusion criteria were as follows:

(1) Current smoker or smoking cessation time of less than 6 months;

(2) Asthma or clinically relevant lung disease other than COPD (lung tuberculosis, restrictive lung disease, idiopathic pulmonary fibrosis, or lung cancer);

(3) Active infection requiring antibiotic therapy;

(4) Active mycobacterial infection;
(5) Clinical relevance unassociated with COPD during screening: left ventricle ejection fraction lower than $40 \%$, valvular heart disease, cardiomyopathy, arrhythmia, congenital heart disease, kidney failure with creatinine index $>2.0 \mathrm{mg} / \mathrm{dl}$, liver disease with AST, ALT or bilirubin twice the upper limit of the normal range, hematological disorder, or cancer;

(6) Using a tumor necrosis factor inhibitor within 3 months of the screening visit;

(7) Using an immunosuppressive medication within 8 weeks of the screening visit;

(8) Active malignancy or history of cancer without recurrence within 5 years prior to screening visit;

(9) Participating in other clinical trials with any medication or medical device;

(10)Being unable to perform all assessments required for the study.

\section{Isolation of umbilical cord-derived mesenchymal stem} cells

The umbilical cord-derived mesenchymal stem cells (UC-MSCs) were cultured and expanded using the UCSCI technology developed by the Stem Cell Institute, VNUHCM University of Science, Ho Chi Minh City, Viet Nam. This technology permits isolating and expanding UC-MSCs from Wharton's jelly and whole umbilical cord tissue. The culture procedure is serumfree and xeno-free.

Umbilical cord samples were collected from donors during childbirth as approved by the local ethics committee. The criteria for umbilical cord tissues were that the tissues were from a full-term birth and negative for $\mathrm{HIV}^{1} / 2, \mathrm{HBV}, \mathrm{HVC}$, and syphilis. All samples used to isolate the UC-MSCs met these criteria (Fig. 2).

Umbilical cord samples were cut into 1-cm-long fragments, then the veins and artery inside were removed, washed twice with washing buffer (PBS), then cut into $1-2 \mathrm{~mm}^{3}$ fragments. These fragments were placed in a T-75 flask with Wharton's jelly contacting the flask surface. Finally, $4 \mathrm{~mL}$ of the MSCCult I medium (DMEM/ F12, supplemented with $7.5 \%$ activated platelet-rich plasma derived from the umbilical cord blood according to the published protocol [25]) was added to each T-75 flask and placed in an incubator at $37^{\circ} \mathrm{C}$ and $5 \% \mathrm{CO}_{2}$. After 3 days, $6 \mathrm{~mL}$ of fresh MSCCult I medium was added to the T-75 flask. The $100 \%$ culture medium was changed with $10 \mathrm{~mL}$ of fresh culture medium after 7 days. When the cells migrated to the fragments and reached $70 \%$ confluence, the tissues were removed, and the cells were subcultured via detachment reagent (Deattachment Solution, Regenmedlab). The UC-MSCs were continuously expanded through 5 passages to obtain sufficient pure cells for transplantation. 


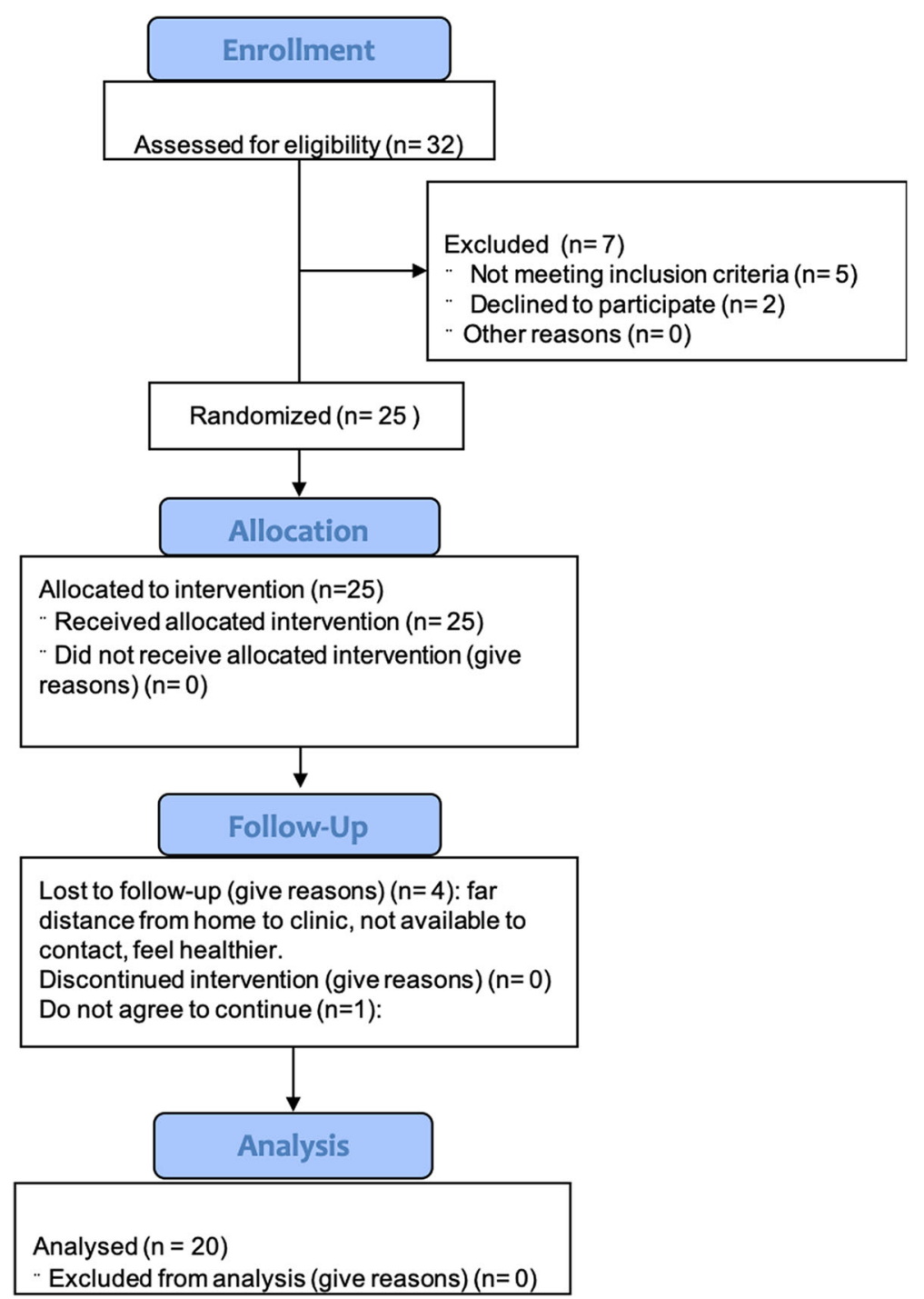

Fig. 1 Flow chart of the study population selection including patient recruitment, exclusion criteria, and refusals

\section{Quality control of the UC-MSC master bank}

After 3-4 passages of the UC-MSCs, 4 flasks were randomly selected from all UC-MSC flasks for quality control. The other flasks were used to collect all UC-MSCs for cryopreservation as the UC-MSC master bank. Quality control for the UC-MSC master bank included identity, purity, safety and potency evaluations.

\section{Identity and purity}

The UC-MSCs were confirmed as MSCs per ISCT recommendations for MSCs. MSCs were observed under an inverted microscope to evaluate their shape. Their phenotypes were evaluated for CD14, CD34, CD44, CD45, CD73, CD90, CD105, and HLA-DR expressions. The protocols for immunophenotyping followed the published protocol [67]. Briefly, cells were washed twice in
PBS containing 1\% bovine serum albumin (Sigma-Aldrich, St. Louis, MO, USA). The cells were then stained with anti-CD14-FITC, anti-CD34-FITC, anti-CD44-PE, anti-CD45-FITC, anti-CD73-FITC, anti-CD90-PE, antiCD105-FITC, or anti-HLA-DR-FITC antibodies (all antibodies were purchased from BD Biosciences, San Jose, CA, USA). Stained cells were analyzed via FACSCalibur flow cytometer (BD Biosciences). Isotype controls were used in all analyses. The purity was calculated based on the percentage of UC-MSCs that were positive for CD44, CD73, CD90, and CD015 and negative for CD14, CD34, CD45, and HLA-DR. The last assay was an in vitro differentiation of the UC-MSCs. This UC-MSC sample was re-evaluated for in vitro differentiation toward adipogenic cells, chondroblasts, and osteoblasts using osteogenic, osteoblast, and chondroblast differentiation kits from 


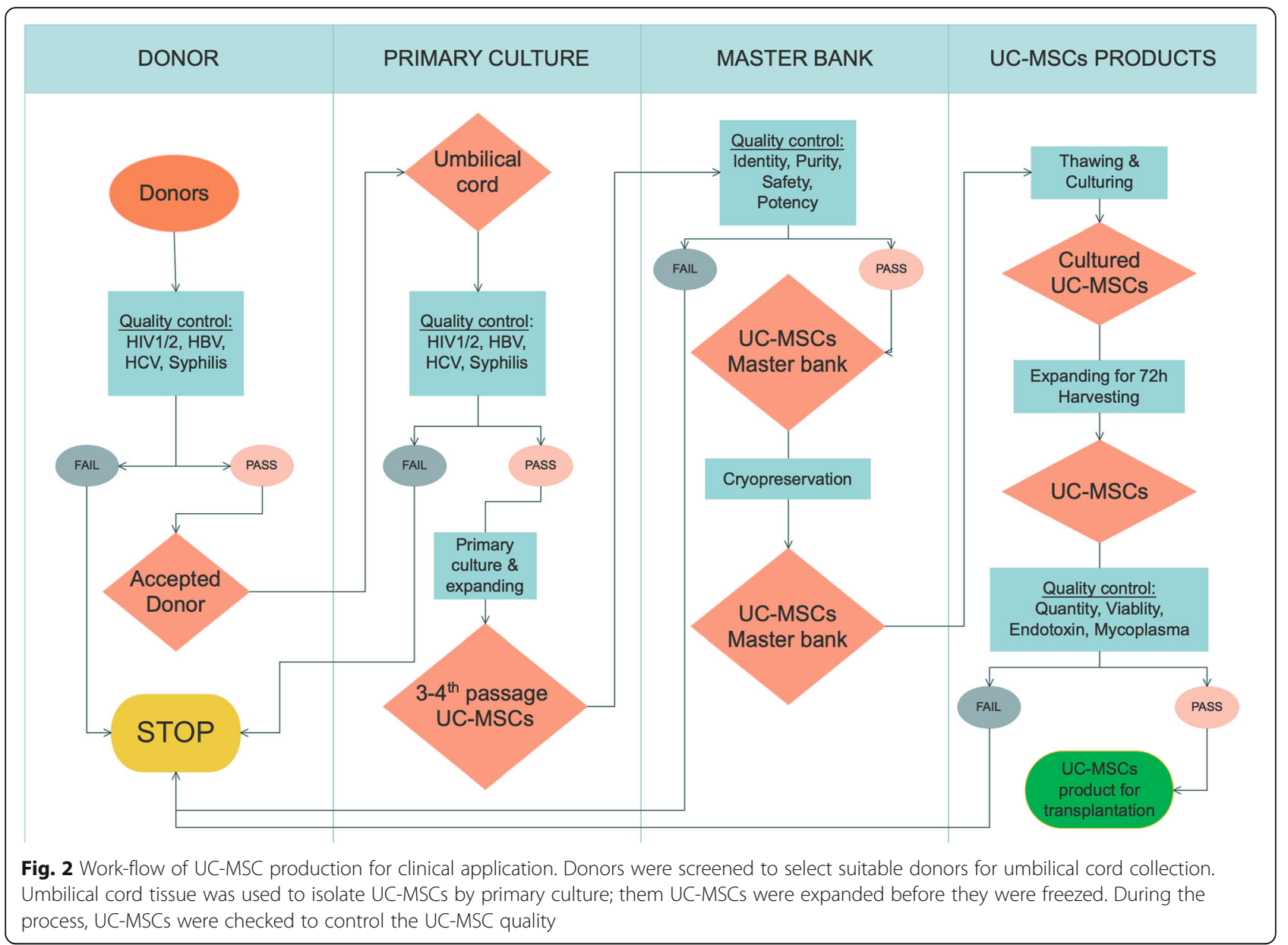

Thermo Fisher Company (Thermo-Fisher, Waltham, MA, USA).

\section{Safety}

UC-MSCs were evaluated for sterility according to USP71, mycoplasma according to USP63, endotoxins according to USP85, and viral infections (HIV 1/2, HBV, $\mathrm{HCV}$ ) via real-time PCR using commercial kits. These cells also were evaluated for in vivo tumorigenicity. The in vivo tumorigenicity was tested by injecting UC-MSCs under the skin of $3 \mathrm{NOD} / \mathrm{SCID}$ mice using GFPexpressing breast cancer stem cells as positive controls (Stem Cell Institute, VNUHCM University of Science). Both breast cancer stem cells and UC-MSCs were injected into the NOD/SCID mice at $5 \times 10^{6}$ cells $/ 100 \mu$ l. UC-MSCs were injected on the right side, while breast cancer stem cells were injected into the left abdominal area. Tumor formation was observed macroscopically for 30 days and checked via in vivo imaging to visualize the positive control using the Extreme II system (Bruker). After being injected with the cells, the mice were continuously monitored for tumor development for 3 months before stopping the experiments.

\section{Potency}

The UC-MSC potency was evaluated by inhibiting the UC-MSCs on allogeneic lymphocyte proliferation as per the published protocol [68]. To prepare the peripheral blood mononuclear cells (PBMCs), PBMCs from the biobank were thawed and incubated in RPMI 1640 medium containing $10 \%$ fetal bovine serum (FBS) at $37^{\circ} \mathrm{C}$ and $5 \% \mathrm{CO}_{2}$ for $3 \mathrm{~h}$ to recover, then collected and labeled with CellTrace ${ }^{\mathrm{Tx}}$ CFSE (Thermo-Fisher, Waltham, MA, USA) per the manufacturer's instructions. The UC-MSCs were prepared by seeding them at 3000 cells $/ \mathrm{cm}^{2}$ in 6-well plates in the MSCCult I medium, then allowed to reach $80 \%$ confluence. The labeled PBMCs were added to MSCs in 6-well plates at a 1:10 ratio (MSC:PBMCs). Next, phytohemagglutinin was added to the RPMI in the wells (PBMCs + MSCs) to a final concentration of $20 \mu \mathrm{g} / \mathrm{mL}$ per well. The negative control for this assay was 250,000 PBMCs per well in a 
six-well plate with complete RPMI medium; the positive control was 250,000 PBMCs per well in a 6-well plate with complete RPMI medium supplemented with a final concentration of $20 \mu \mathrm{g} / \mathrm{mL}$ phytohemagglutinin. After 3 and 5 days, 3 wells from the 6-well plates were collected to analyze the proliferating $\mathrm{T}$ cell population. The $\mathrm{T}$-cell proliferation percentage was calculated based on the negative or lower CFSE signal compared with the positive and negative control samples. All samples were analyzed via flow cytometer (FACSCalibur; BD Bioscience, Franklin Lakes, NJ, USA) with CellQuest Pro software.

\section{Preparation of UC-MSCs for transplantation}

The thawed UC-MSCs were cultured for $72 \mathrm{~h}$, then harvested for transplantation, isolated with deattachment reagent, washed twice with washing buffer, and resuspended in saline solution for transfusion. The quantity and viability of the UC-MSCs were evaluated using a C6 Accuri flow cytometer (BD Bioscience). Mycoplasma contamination was evaluated according to USP63, and endotoxins according to USP85. Cell viability was evaluated based on 7-AAD expression and detected by the FL3 channel in the flow cytometer (BD Accuri C6, BD Bioscience). Data were collected and analyzed using CellQuest Pro software.

The population doubling time (DT) of UC-MSCs after thawing and recovery was determined. The doubling time was calculated using the formula DT $=(\mathrm{t} 2-\mathrm{t} 1) \ln (2) /$ $\ln (\mathrm{n} 2 / \mathrm{n} 1)$ where $\mathrm{n} 2$ is the cell number at harvesting, $\mathrm{n} 1$ is the cell number at plating, $\mathrm{t} 2$ is the time at cell harvest and $\mathrm{t} 1$ is the time at plating.

\section{Study treatments and outcome evaluations}

Enrolled patients were intravenously infused with $1.5 \times$ $10^{6}$ fresh allogeneic MSCs $/ \mathrm{kg}$ directly harvested from the T-75 flasks on day 0 . UC-MSCs were delivered at a maximum rate of $2.0 \times 10^{6} \mathrm{cells} / \mathrm{min}$. Each infusion took approximately $45 \mathrm{~min}$ to complete.

Participants were subsequently evaluated for safety and efficacy at 1, 3, and 6 months. Safety was assessed by the occurrence of adverse events during either the study or the drug infusion by physician assessments, laboratory evaluations, and electrocardiograms (ECGs), as well as ECGs during the 6-month follow-up period.

A record of COPD exacerbations was maintained for each patient. Efficacy measures included improvement from baseline in pulmonary functions $\left(\mathrm{FEV}_{1}, \mathrm{FVC}\right.$, $\mathrm{FEV}_{1} / \mathrm{FVC}$, total lung capacity by plethysmography, single-breath carbon monoxide diffusing capacity, exercise performance (6-min walk test [6MWT]), dyspnea assessment (Borg scale), and quality of life (St. George's Respiratory Questionnaire and global assessment of patient status). COPD exacerbations were assessed as the time to first exacerbation and the ratio of the rate of exacerbations in UC-MSC-treated patients.

\section{Statistical analysis}

The number of patients was selected for the initial safety assessments and exploratory evaluation of efficacy. For all other end-points, statistical analyses were performed using two-sided hypothesis tests, including $t$ tests, $X^{2}$ tests, Wilcoxon rank-sum tests, or Fisher's exact tests as appropriate, at the 0.05 significance level. Differences in time to first COPD exacerbation and probabilities of being exacerbation-free were assessed via Kaplan-Meier methodology and log-rank tests. Total COPD exacerbations experienced per patient and adjusted per exposure were compared between treatment groups using a twosided Mantel-Haenszel $\chi^{2}$ test for ordered categorical data.

\section{Results}

\section{Isolation of UC-MSCs and establishment of UC-MSC master bank}

After the 4th subculture, UC-MSCs were used to perform control quality for the master bank with identity, purity, safety, and potency assays.

UC-MSCs adhered well to the plastic flask surface and exhibited a fibroblast-like shape (Fig. 3). At passage 4, the cells showed expression of the common MSC markers,

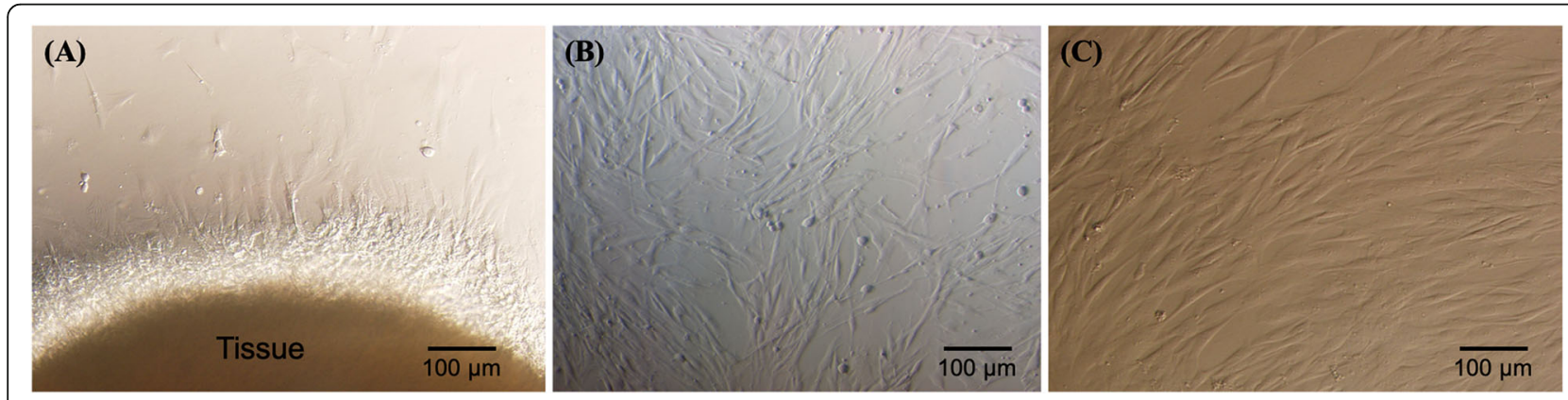

Fig. 3 UC-MSC culture and expansion. The MSCs migrated from the tissue after 7 days of primary culture (a). They were subcultured for UC-MSC mater banks (b). The UC-MSCs were thawed and cultured for transplantation (c) 
CD44 (100\%), CD73 (98 $\pm 0.11 \%), \quad C D 90$ (100\%), and CD105 (95.42 $\pm 2.13 \%)$. However, the UC-MSCs were negative (or low) for the hematopoietic markers, CD14 (0.21 $\pm 0.04 \%), \quad$ CD34 $\quad(0.013 \pm 0.09 \%), \quad$ CD $45 \quad(0.12 \pm$ $0.10 \%)$, and HLA-DR (0.04 $\pm 0.01 \%)$ (Fig. 4).

UC-MSCs were successfully differentiated into osteoblasts, adipocytes, and chondroblasts. In the induced medium geared toward osteoblast differentiation, UCMSCs gradually changed their morphology to a longer shape and gradually produced more matrix. After 21 days of induction, the differentiated samples stained positive with Alizarin red. The dyes combined with calcium in the matrix and displayed the red color. UCMSCs were also successfully differentiated into adipocytes. These cells accumulated lipid droplets in the cytoplasm, which were stained with oil red O. Differentiation of UC-MSCs into chondroblasts was also recorded in vitro after inducing MSCs for 21 days in the induced medium. Overexpression and accumulation of proteoglycans and collagen I were evaluated in these differentiated cells by alcian blue staining (Fig. 5).

The mycoplasma assay showed that all UC-MSC samples were negative for mycoplasma; endotoxins were < $0.025 \mathrm{EU} / \mathrm{mL}$. The culture supernatant was negative for HIV1/2, HBV, and HCV. After 30 days and 3 months, the UC-MSCs caused no tumors in the NOD/SCID mice.

Figure 6 shows the UC-MSC potency, indicating that the UC-MSCs efficiently inhibited $\mathrm{T}$ cell proliferation.
Proliferation of PHA-treated T cells was significantly reduced when cocultured with UC-MSCs for 3 and 5 days. On day 3 , T cell proliferation percentages were $3.33 \pm$ $1.53 \%, 2.00 \pm 1.00 \%, 40.00 \pm 5.00 \%$, and $12.33 \pm 2.52 \%$; respectively, for $\mathrm{PBMC}, \mathrm{PBMC}+\mathrm{UC}, \mathrm{PBMC}+\mathrm{PHA}$, and $\mathrm{PBMC}+\mathrm{PHA}+\mathrm{UC}$ groups. UC-MSCs could efficiently inhibit $\mathrm{T}$ cell proliferation $(p<0.05)(12.33 \pm 2.52 \%$ in $\mathrm{PBMC}+\mathrm{PHA}+\mathrm{UC}$ group vs $40.00 \pm 5.00 \%$ in PBMC+PHA group). After 5 days, $\mathrm{T}$ cell proliferation percentage significantly increased in $\mathrm{PBMC}$ group compared to $\mathrm{PBMC}+\mathrm{UC}$ group $(35 \pm 5.00 \%$ vs. $14.00 \pm 2.00 \%$, respectively); and in $\mathrm{PBMC}+\mathrm{PHA}$ compared to $\mathrm{PBMC}+\mathrm{PHA}+\mathrm{UC}$ group $(p<0.05) \quad(71.67 \pm 7.64 \%$ vs. $20.00 \pm 3.00 \%)$. These results showed that UC-MSCs could inhibit $\mathrm{T}$ cell proliferation in both PHA and without PHA treatment.

These results showed that the UC-MSC samples satisfied all the criteria for establishing the master bank.

\section{Preparation of UC-MSCs for transplantation}

The UC-MSCs from the master bank were thawed and recovered for $72 \mathrm{~h}$. The doubling time was determined to control cell recovery. The DT of UC-MSCs after $72 \mathrm{~h}$ culture was $40.56 \pm 1.68 \mathrm{~h}$, similar to before cryopreservation $(p>0.05)$. All samples were free mycoplasma; and endotoxins were $<0.025 \mathrm{EU} / \mathrm{mL}$. The percentage of viable cells was $>99 \%$ for all samples.

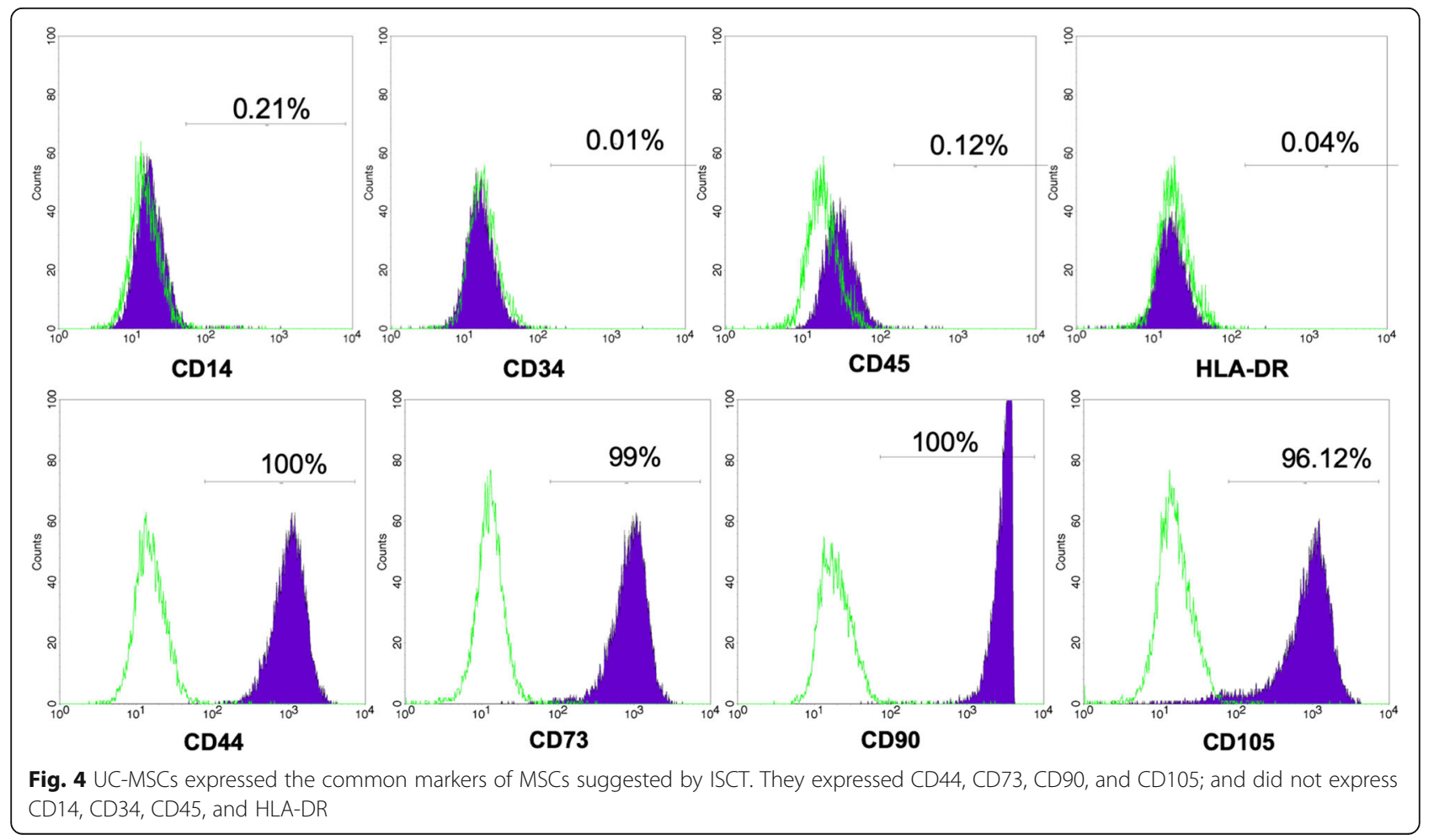



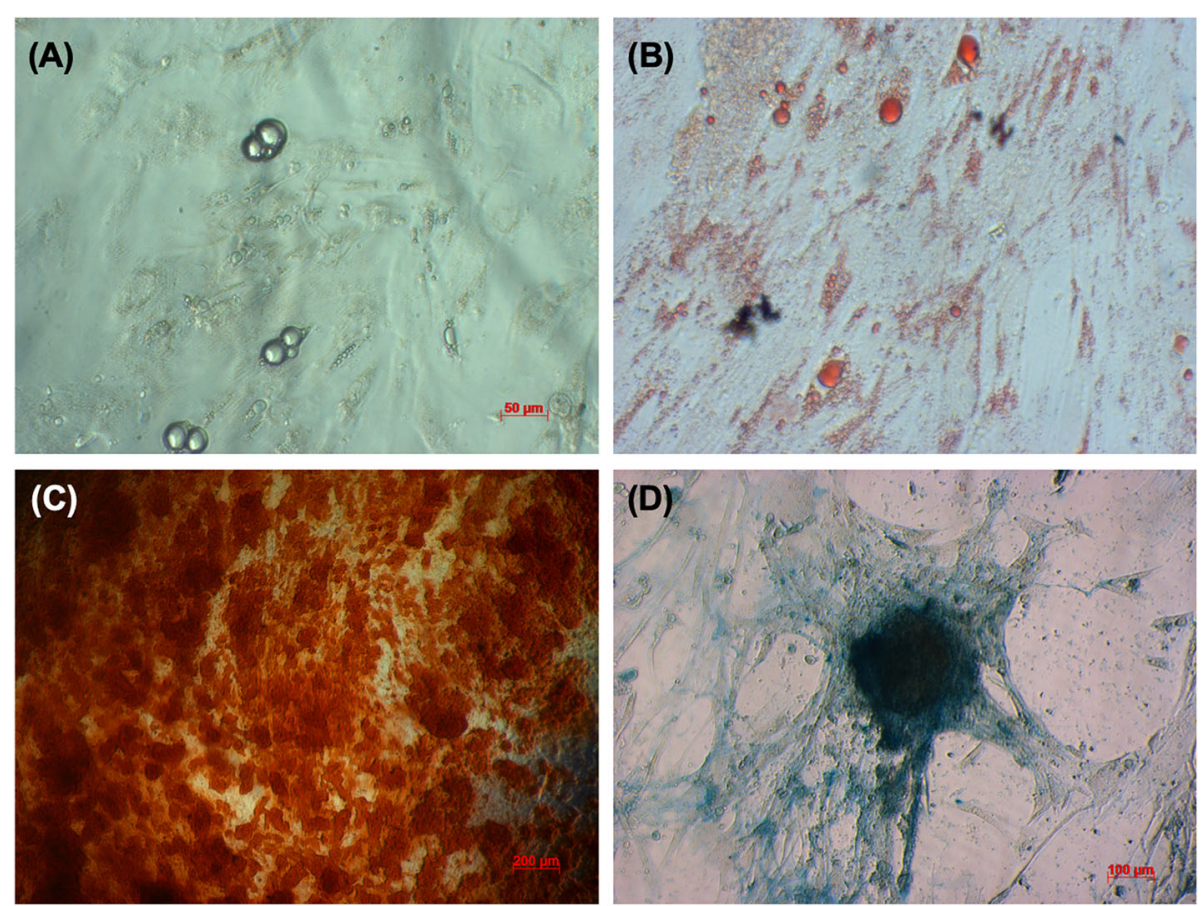

Fig. 5 UC-MSCs were successfully differentiated into adipocytes, osteoblasts, and chondroblasts. After differentiation, UC-MSCs successfully differentiated into adipocytes (a) that were positive with Oil Red staining (b); into osteoblasts that positive with Alizarin red staining (c); into chondroblasts that positive with Alcian blue staining (d)

\section{Characterization of patients}

Table 1 shows patient characteristics. Twenty men were enrolled in this study; 9 patients were at stage $C$, and 11 were at stage $D$. The average age of the patients was 67 years, with no significant differences between groups for stage $\mathrm{C}$ and stage $\mathrm{D}$ patients. Most patients $(19 / 20)$ were smokers with an average of 17.5 pack-years. Disease duration differed significantly between stage C (3.0 years) and stage D (11 years) patients.

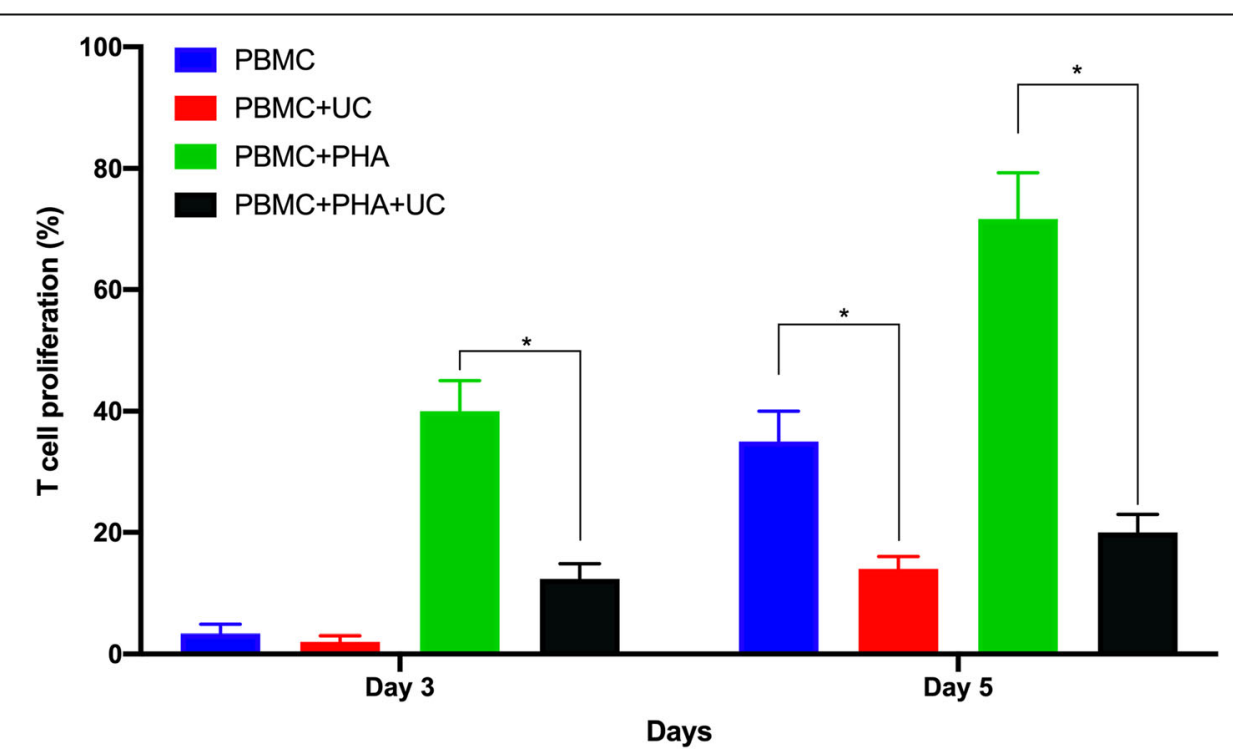

Fig. 6 UC-MSCs can inhibit T cell proliferation after 3 and 5 days co-culture. After 3 days of co-culture with PBMC, UC-MSCs can efficiently PHAtreated PBMC proliferation. After 5 days of co-culture, UC-MSCs can strongly inhibit the both PHA-treated PBMC and non-treated PBMC proliferation 
Table 1 Baseline characteristics of the study patients

\begin{tabular}{llll}
\hline & All patients $(n=20)$ & Stage C $(n=9)$ & Stage D $(n=11)$ \\
\hline Male sex, $n(\%)$ & $20(100 \%)$ & $9(100 \%)$ & $11(100 \%)$ \\
Age, years & $67(55,81)$ & $65(59,81)$ & $68(55,81)$ \\
Disease duration, years & $6.0(1,25)$ & $3.0(1,10)$ & $11(2,25)$ \\
Smoker/former smoker, $n(\%)$ & $19(95 \%)$ & $8(88.9 \%)$ & $11(100 \%)$ \\
Smoking amount, pack-years* & $17.5(0.0,70.0)$ & $15.0(0.0,65.0)$ & $20.0(3.0,70.0)$ \\
Had quit smoking, $n(\%)^{*}$ & $19(100 \%)$ & $8(100 \%)$ & $11(100 \%)$ \\
Time since quitting smoking, years* & $9.5(0.0,39.0)$ & $6.0(0.0,39.0)$ & $10.0(3.0,24.0)$ \\
\hline
\end{tabular}

\section{Safety outcomes}

UC-MSC infusions were well tolerated, and no serious or clinically significant adverse events were observed over the course of the study or drug infusions for all patients. No significant changes in oxygen saturation or heart rate were observed during the infusions (Table 2).

\section{Clinical outcomes before treatment and during follow-up according to GOLD stage}

Table 3 shows the clinical outcomes. FEV1 was slightly altered before (34\%) and after treatment at 1 (35\%), 3 $(33.0 \%)$ and $6(33.5 \%)$ months $(p>0.05)$. No statistically significant differences in CRP or $6 \mathrm{MWT}$ were observed for 6 months before and after treatment. The mean CRP level decreased from $3.3 \mathrm{mg} / \mathrm{dL}$ before treatment to 2.2 , 2.4 , and $2.3(\mathrm{mg} / \mathrm{dL})$ after treatment at 1,3 , and 6 months, respectively. The 6MWT increased from 360.0 in patients before treatment to $380,360.0$, and 380.0 after 1,3 , and 6 months of treatments, respectively $(p>$ $0.05)$.

The mMRC, CAT score, and number of exacerbations decreased significantly after 1,3 , and 6 months compared with those before treatment; this reduction was maintained for 1-6 months after treatment. The mMRC value strongly decreased from 1.0 before treatment to 0.0 after treatment at 1,3 , and 6 months $(p<0.05)$. Similarly, the CAT scores were also significantly reduced from 10.05 before treatment to 6.5 at 1 month after

Table $\mathbf{2}$ Incidence of adverse events

\begin{tabular}{|c|c|c|}
\hline \multirow[t]{2}{*}{ System organ class/preferred term } & \multicolumn{2}{|l|}{ Subjects, no. } \\
\hline & Stage $C(n=9)$ & Stage $D(n=11)$ \\
\hline Cardiac disorders & 0 & 0 \\
\hline Congestive heart failure & 0 & 0 \\
\hline Gastrointestinal disorders & 0 & 0 \\
\hline GERD & 0 & 0 \\
\hline Peripheral edema & 0 & 0 \\
\hline Immune system disorders & 0 & 0 \\
\hline Seasonal allergies & 0 & 0 \\
\hline Infections and infestations & 0 & 0 \\
\hline Bronchitis & 0 & 0 \\
\hline Nasopharyngitis & 0 & 0 \\
\hline Pneumonia & 0 & 0 \\
\hline Skin infection & 0 & 0 \\
\hline Upper respiratory tract infection & 0 & 0 \\
\hline Urinary tract infection & 0 & 0 \\
\hline Blood calcium increase & 0 & 0 \\
\hline Transient C-reactive protein increase & 3 & 2 \\
\hline Metabolic and nutritional disorders & 0 & 0 \\
\hline Hyperglycemia & 0 & 0 \\
\hline Type 2 diabetes mellitus & 0 & 0 \\
\hline Transient hypertension & 5 & 4 \\
\hline
\end{tabular}


Table 3 Comparison of clinical outcomes before and after treatment

\begin{tabular}{|c|c|c|c|c|c|c|c|}
\hline Outcome & $\begin{array}{l}\text { Before treatment }(N= \\
\text { 20) }\end{array}$ & $\begin{array}{l}\text { After } 1 \text { month }(N= \\
\text { 20) }\end{array}$ & $\begin{array}{l}p \\
\text { value }^{*}\end{array}$ & $\begin{array}{l}\text { After } 3 \text { months ( } N= \\
\text { 20) }\end{array}$ & $\begin{array}{l}p \\
\text { value* }\end{array}$ & $\begin{array}{l}\text { After } 6 \text { months }(N= \\
\text { 20) }\end{array}$ & $\begin{array}{l}p \\
\text { value* }\end{array}$ \\
\hline FEV1 (\%) & $34.0(24.6,49.0)$ & $35.0(25.5,55.2)$ & 0.107 & $33.0(26.5,51.0)$ & 0.251 & $33.5(27.5,43.0)$ & 0.239 \\
\hline CRP (mg/dL) & $3.3(1.4,5.8)$ & $2.2(1.4,4.0)$ & 0.444 & $2.4(1.2,6.1)$ & 0.702 & $2.3(1.3,5.3)$ & 0.284 \\
\hline $\mathrm{mMRC}$ & $1.0(0.0,2.0)$ & $0(0.0,1.0)$ & 0.033 & $0(0.0,1.0)$ & 0.005 & $0(0.0,1.0)$ & 0.017 \\
\hline CAT & $10.5(5.8,14.5)$ & $6.5(2.8,8.8)$ & 0.002 & $4.0(2.8,7.2)$ & 0.001 & $2.0(1.0,7.5)$ & 0.003 \\
\hline $6 \mathrm{MWT}$ & $360.0(330.0,420.0)$ & $380.0(350.0,400.0)$ & 0.246 & $360.0(347.5,405.0)$ & 0.521 & $380.0(355.0,420.0)$ & 0.250 \\
\hline $\begin{array}{l}\text { Number of } \\
\text { exacerbations }\end{array}$ & $2(2,4)$ & - & - & - & - & $0(0,1)$ & $\begin{array}{l}< \\
0.001\end{array}$ \\
\hline
\end{tabular}

Note: Summary statistic is median (interquartile range). ${ }^{*} p$ value was calculated based on Wilcoxon signed-rank test comparing outcomes before treatment with those at each follow-up (1, 3, and 6 months). Abbreviations: FEV1 forced expiratory volume in $1 \mathrm{~s}$, CRP C-reactive protein, mMRC Modified Medical Research Council, CAT COPD assessment test, 6MWT 6-min walk test

treatment, 4.0 at 3 months after treatment, and 2.0 at 6 months after treatment $(p<0.05)$. The COPD exacerbations were dramatically reduced from 2 before treatment to 0 at 6 months after treatment $(p<0.05)$.

\section{Efficacy in stage $C$ and $D$ patients}

To evaluate the effects of transplantation on treatment efficacy at stages C and D of COPD, we separated patients into 2 groups, with 9 patients at stage $C$ and 11 at stage D. Figure 7 and Table 4 present the results, which suggest that UC-MSC transplantation yielded better results for stage D COPD patients than for stage C COPD patients.

Stage D COPD patients presented significantly improved mMRC and CAT values after 3 months of treatment and significantly improved FEV1, CAT score, and numbers of exacerbations after 6 months of treatment $(p<0.05)$. The other values did not significantly change after 3 and 6 months $(p>0.05$; Table 4$)$. After 6 months, the CRP values were reduced by approximately $40 \%$ compared with those before treatment in both groups, but this reduction was not significant.
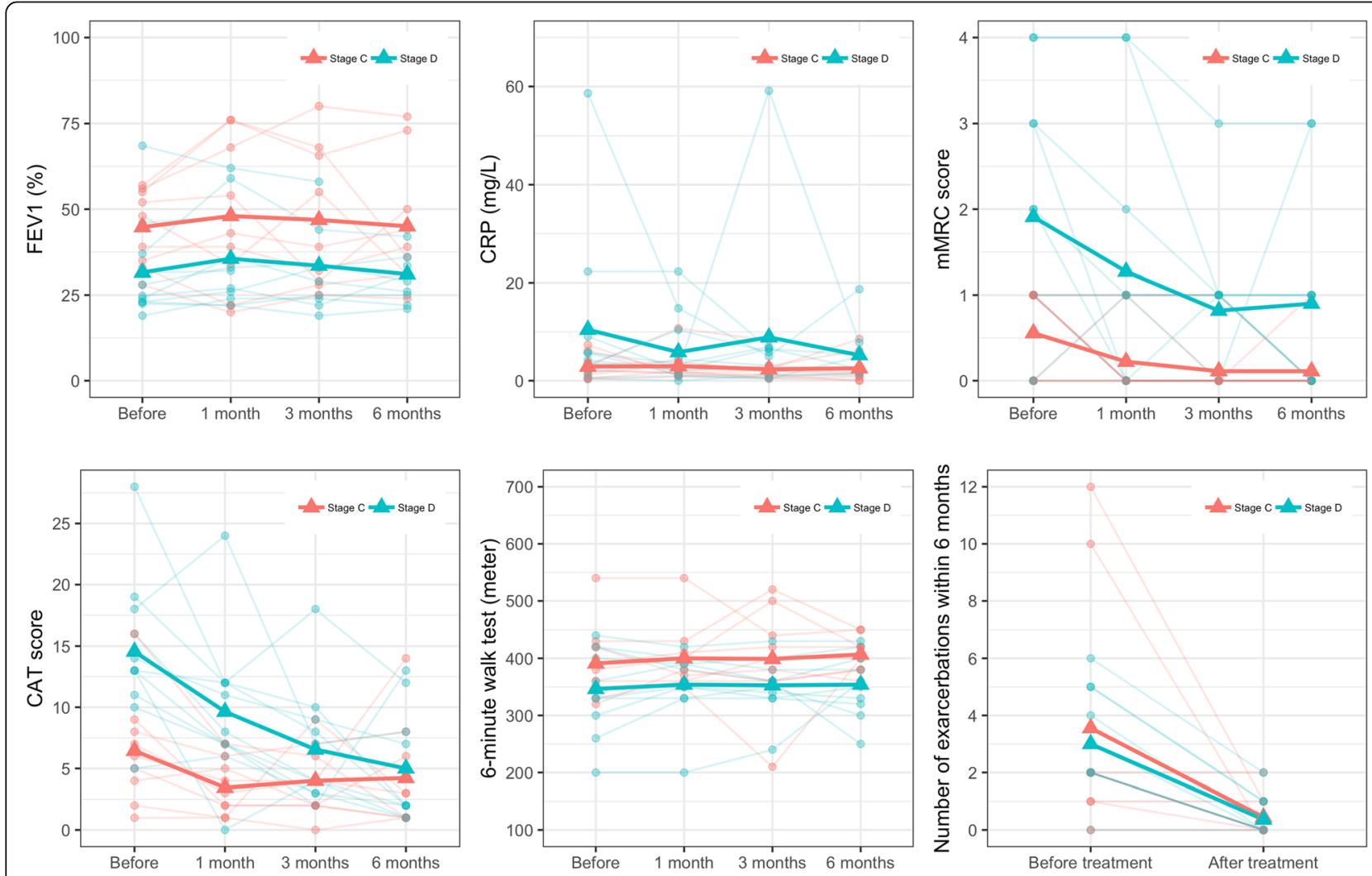

Fig. 7 Clinical outcomes before treatment and during follow-up period by GOLD stages (C and D stages) 
Table 4 Comparison of clinical outcomes before and after treatment in stage $C$ and D patients

\begin{tabular}{|c|c|c|c|c|c|c|c|}
\hline Outcome & Before treatment $(N=20)$ & After 1 month $(N=20)$ & $p$ value* & After 3 months $(N=20)$ & $p$ value* & After 6 months $(N=20)$ & $p$ value* \\
\hline \multicolumn{8}{|l|}{ FEV1 (\%) } \\
\hline Stage C & $48(35-55)$ & $43(34-68)$ & 0.477 & $39(29-65.6)$ & 0.516 & $39(31-50)$ & 0.922 \\
\hline Stage D & $24.8(23-37)$ & $32(24-48)$ & 0.079 & $31(24-44)$ & 0.309 & $30(25-36)$ & 0.022 \\
\hline \multicolumn{8}{|l|}{ CRP (mg/dL) } \\
\hline Stage $C$ & $2.2(1.2-3.3)$ & $1.9(1.5-3.5)$ & 0.914 & $1.9(1.2-2.4)$ & 0.547 & $1.5(0.8-6.2)$ & 0.688 \\
\hline Stage D & $4.2(1.5-9)$ & $2.9(2.2-10.4)$ & 0.375 & $5(1.1-6.6)$ & 0.966 & $2.8(2.3-5.3)$ & 0.426 \\
\hline \multicolumn{8}{|l|}{$\mathrm{mMRC}$} \\
\hline Stage C & $1(0-1)$ & $0(0-0)$ & 0.375 & $0(0-0)$ & 0.125 & $0(0-0)$ & 0.219 \\
\hline Stage D & $2(1-3)$ & $1(0-2)$ & 0.156 & $1(0-1)$ & 0.031 & $0.5(0-1)$ & 0.094 \\
\hline \multicolumn{8}{|l|}{ CAT } \\
\hline Stage C & $6(4-8)$ & $3(2-5)$ & 0.023 & $4(2-6)$ & 0.082 & $3(1-6)$ & 0.375 \\
\hline Stage D & $13(11-18)$ & $8(7-12)$ & 0.023 & $4(3-9)$ & 0.001 & $2(2-8)$ & 0.004 \\
\hline \multicolumn{8}{|l|}{$6 \mathrm{MWT}$} \\
\hline Stage C & $380(350-420)$ & $380(360-410)$ & 0.375 & $400(360-440)$ & 0.793 & $400(380-420)$ & 0.527 \\
\hline Stage D & $350(300-420)$ & 365 (330-390) & 0.539 & $360(330-380)$ & 0.578 & 355 (320-400) & 0.509 \\
\hline \multicolumn{8}{|c|}{ Number of exacerbations } \\
\hline Stage C & $2(1-2)$ & - & - & - & & $0(0-1)$ & 0.031 \\
\hline Stage D & $2(2-5)$ & - & - & - & & $0(0-1)$ & 0.002 \\
\hline
\end{tabular}

\section{Discussion}

COPD is a chronic inflammatory condition in the lungs, possibly related to smoking. Current treatment for COPD involves the use of anti-inflammatory agents combined with other therapies. However, current therapies have limited efficacy. This study showed that allogeneic non-HLA-matched UC-MSC transplantation is a safe treatment that improved the quality of life of COPD patients. This clinical study was the first to use allogeneic MSCs from umbilical cord tissue to treat COPD.

First, UC-MSCs were isolated and expanded from human umbilical cord tissues. The umbilical cord tissue was carefully checked for viral infections, including HIV1/2, $\mathrm{HBV}, \mathrm{HCV}$, and syphilis. Only samples that were negative for these viruses were used to isolate the UC-MSCs. Before the UC-MSCs were used to treat patients, all samples were inspected for quality. The UC-MSCs satisfied all essential criteria for MSCs and cellular products for clinical applications. The MSCs displayed the standard MSC phenotypes: positive for CD44, CD73, CD90, and CD105 and negative for CD14, CD34, CD45, and HLA-DR. They also maintained the capacity to differentiate into osteoblasts, chondrocytes, and adipocytes in vitro. Furthermore, the MSCs were negative for mycoplasma, bacteria, and fungi and were low for endotoxins. The MSC karyotyping was normal (data not shown). The MSC potency was reported previously [60]. The UC-MSCs collected via our protocols exhibited stronger immunomodulation than that of adipose-derived and bone marrow-derived MSCs.
These cells were then infused into COPD patients at $1.5 \times 10^{6} \mathrm{UC}-\mathrm{MSCs} / \mathrm{kg}$. For 6 months from day 0 , all patients at both stages tolerated the MSCs well with no severe or significant adverse effects.

More importantly, the UC-MSC transplantation significantly improved some important outcomes of COPD, including mMCR, CAT, and number of exacerbations. At 1,3 , and 6 months post-transplantation, the CAT and mMCR were significantly reduced $(p<0.05)$, and the number of exacerbations was significantly reduced toward 0 over the 6 months post-transplantation. These clinical outcomes were likely due to downregulated inflammation. The mean CRP decreased from $3.3 \mathrm{mg} / \mathrm{dL}$ to $2.3 \mathrm{mg} / \mathrm{dL}$ after 6 months; however, this change was not statistically significant, possibly because of the small number of patients in the study. Similarly, the $6 \mathrm{MWT}$ score also increased from 360 to 380 but not significantly.

These clinical data showed that UC-MSC transplantation positively affected COPD treatment. In a previous report, we reported two cases of stage D COPD patients who were successfully treated via allogeneic UC-MSC transplantation [69].

To date, this is the first clinical trial to use UC-MSCs in COPD treatment. Several clinical trials registered in clinicaltrials.gov were performed to treat this disease using BM-MSCs or adipose-derived stem cells. Only three of these were completed and reported the results. One trial used allogeneic BM-MSCs, and the other two 
used autologous BM-MSCs. These clinical trials were performed in moderate-to-severe COPD patients.

The first clinical trial was completed in the USA (NCT00683722) [50]. Sixty-two patients with moderateto-severe COPD were randomized to intravenously receive an infusion of either ex vivo cultured allogeneic BM-MSCs (Prochymal, Osiris Therapeutics, Inc.) at 100 million MSCs/infusion or a control vehicle. The results showed that during the 2 years of follow-up, the BMMSC-treated patients had no serious adverse effects or increased COPD exacerbation frequencies. However, although the CRP values decreased in the MSC-treated group, the pulmonary function testing as well as quality of life indicators was not significantly improved compared with those of the nontreatment group [50].

The other two clinical trials (NCT01110252 and NCT01306513) used autologous BM-MSCs to treat COPD patients. In study NCT01110252, 4 patients were transplanted with autologous BM-MSCs and followed for 2 years; no patients experienced adverse effects. Laboratory parameters, clinical conditions, and quality of life were slightly improved [51, 52]. Similarly, in the third clinical trial (NCT01306513), 7 patients were intravenously infused with autologous BM-MSCs [53]. After 1 year of follow-up, no adverse effects related to BMMSCs were detected, and only one 3-fold increase in CD31 in the alveolar septa was recorded [53].

In contrast to these clinical trials, UC-MSC transplantation significantly improved the quality of life and clinical conditions of COPD patients, possibly due to the strong immunomodulation capacity of the UC-MSCs compared with that of BM-MSCs reported in some publications $[60,70]$. This may be due to the antiinflammatory effects of UC-MSCs, which are stronger immunomodulatory cells than are MSCs from adipose tissue or bone marrow [60]. These cells effectively inhibited the T cells, B cells, and NK cells via various mechanisms [60, 71-73].

UC-MSCs have been reported as promising MSC sources for treating various diseases in humans, including heart failure [74], type 2 diabetes mellitus [75], ankylosing spondylitis [76], and angioplasty for diabetic feet [77].

In this study, we analyzed the efficacy of UC-MSC transplantation in stage C and D COPD patients. Stage $\mathrm{D}$ patients responded more strongly to the treatment than did stage $\mathrm{C}$ patients. Most clinical outcomes of CODP remained reduced after 6 months of treatment, including the CRP, mMRC score, CAT score, and number of exacerbations, while the 6MWT score was slightly increased in stage D COPD patients.

\section{Conclusion}

In summary, systemic administration of UC-MSCs appears safe. The initial results also showed that UC-MSCs transplantation improved mMRC, CAT scores, and number of exacerbations in an older, comorbid population of moderate-to-severe COPD patients with compromised lung function. Treatment efficacy did not significantly differ between stage $\mathrm{C}$ and stage D COPD patients; however, stage D COPD patients exhibited a stronger medical response after UC-MSC transplantation than did stage C COPD patients. Although this is a pilot study, these primary results provide an important and significant basis for further clinical investigations of MSCs in patients with COPD.

\section{Abbreviations}

6MWT: 6-min walk test; CAT: COPD assessment test; CRP: C-reactive protein; ECG: Electrocardiogram; FEV1: Forced expiratory volume in $1 \mathrm{~s}$; GVHD: Graft versus host disease; HBV: Hepatitis B virus; HCV: Hepatitis C virus; HIV1/ 2: Human immunodeficiency viruses 1/2; HLA: Hyman leukocyte antigen; mMRC: Modified Medical Research Council; MSC: Mesenchymal stem cell; UC: Umbilical cord; VNUHCM: Viet Nam National University, Ho Chi Minh city

\section{Acknowledgements}

Not applicable.

\section{Authors' contributions}

PLTB, HNT, DQ, HDK, DLV, LNH, KMC, TTB, and TDM designed the experiments, recruited the patients, transplanted stem cells to the patients, monitored, and collected the data from the patients. PLTB and DQ analyzed the data and explained the results. HDNC, TPV, NVB, and NTC prepared the stem cells from the umbilical cord and expanded stem cells. PVP and PLTB characterized the stem cells; prepared the media for culture, and wrote the manuscript. All authors read and approved the final manuscript.

\section{Funding}

This research was partly funded by the Ministry of Science and Technology, Vietnam under grant number KC.10.15/16-20; and grant number DM.10.DA/ 15.

\section{Availability of data and materials}

Data and materials used and/or analyzed during the current study are available from the corresponding author on reasonable request.

\section{Ethics approval and consent to participate}

This study was conducted in accordance with the amended Declaration of Helsinki. The institutional review board (scientific and ethical committee) of Van Hanh General Hospital (Ho Chi Minh City, Viet Nam, no. 084/2017/QD$\mathrm{NCKH}$ ) and Vietnam Military Academy 103 (Hanoi, Vietnam) approved the

study, and all participants provided written informed consent.

\section{Consent for publication}

Not applicable.

\section{Competing interests}

The authors declare that they have no competing interests.

\section{Author details}

${ }^{1}$ Van Hanh General Hospital, Ho Chi Minh City, Viet Nam. ${ }^{2}$ Vietnam Millitay Academy 103, Ha Noi, Viet Nam. ${ }^{3}$ Stem Cell Institute, VNUHCM University of Science, Ho Chi Minh City, Viet Nam. ${ }^{4}$ Laboratory of Stem Cell Research and Application, VNUHCM University of Science, Ho Chi Minh City, Viet Nam.

Received: 18 October 2019 Revised: 2 January 2020

Accepted: 4 February 2020 Published online: 13 February 2020

\section{References}

1. McEvoy CE, Niewoehner DE. Adverse effects of corticosteroid therapy for COPD: a critical review. Chest. 1997;111(3):732-43. 
2. McEvoy CE, Niewoehner DE. Corticosteroids in chronic obstructive pulmonary disease: clinical benefits and risks. Clin Chest Med. 2000;21(4): 739-52

3. Chang Y-P, Lai C-H, Lin C-Y, Chang Y-C, Lin M-C, Chong I-W, Sheu C-C, Wei Y-F, Chu K-A, Tsai J-R. Mortality and vertebral fracture risk associated with long-term oral steroid use in patients with chronic obstructive pulmonary disease: a systemic review and meta-analysis. Chronic Respir Dis. 2019;16: 1479973119838280.

4. Locatelli F, Algeri M, Trevisan V, Bertaina A. Remestemcel-L for the treatment of graft versus host disease. Expert Rev Clin Immunol. 2017;13(1): 43-56.

5. Kurtzberg J, Prockop S, Teira P, Bittencourt H, Lewis V, Chan KW, Horn B, Yu L, Talano J-A, Nemecek E. Allogeneic human mesenchymal stem cell therapy (remestemcel- $L$, Prochymal) as a rescue agent for severe refractory acute graft-versus-host disease in pediatric patients. Biol Blood Marrow Transplant. 2014;20(2):229-35.

6. Elgaz S, Kuçi Z, Kuçi S, Bönig H, Bader P. Clinical use of Mesenchymal stromal cells in the treatment of acute graft-versus-host disease. Transfus Med Hemother. 2019;46(1):27-34.

7. Lu L, Dai C, Zhang Z, Du H, Li S, Ye P, Fu Q, Zhang L, Wu X, Dong Y. Treatment of knee osteoarthritis with intra-articular injection of autologous adipose-derived mesenchymal progenitor cells: a prospective, randomized, double-blind, active-controlled, phase Ilb clinical trial. Stem Cell Res Ther. 2019;10(1):143

8. Ra JC, Kang SK, Shin IS, Park HG, Joo SA, Kim JG, Kang B-C, Lee YS, Nakama K, Piao M. Stem cell treatment for patients with autoimmune disease by systemic infusion of culture-expanded autologous adipose tissue derived mesenchymal stem cells. J Transl Med. 2011;9(1):181.

9. Rajaram R, Subramani B, Abdullah BJ, Mahadeva S. Mesenchymal stem cell therapy for advanced liver cirrhosis: a case report. JGH Open. 2017;1(4):1535.

10. Chisholm J, Ruff C, Viswanathan S. Current state of Health Canada regulation for cellular and gene therapy products: potential cures on the horizon. Cytotherapy. 2019.

11. Park YB, Ha CW, Lee CH, Yoon YC, Park YG. Cartilage regeneration in osteoarthritic patients by a composite of allogeneic umbilical cord bloodderived mesenchymal stem cells and hyaluronate hydrogel: results from a clinical trial for safety and proof-of-concept with 7 years of extended followup. Stem Cells Transl Med. 2017;6(2):613-21.

12. Negoro T, Takagaki $Y$, Okura H, Matsuyama A. Trends in clinical trials for articular cartilage repair by cell therapy. NPJ Regen Med. 2018;3(1):17.

13. Okada K, Miyata T, Sawa Y. Insurance systems and reimbursement concerning research and development of regenerative medicine in Japan. Regen Med. 2017;12(2):179-86

14. Kozlowska U, Krawczenko A, Futoma K, Jurek T, Rorat M, Patrzalek D, Klimczak A. Similarities and differences between mesenchymal stem/ progenitor cells derived from various human tissues. World J Stem Cells. 2019;11(6):347-74.

15. Antebi B, Walker KP III, Mohammadipoor A, Rodriguez LA, Moore RK, Cancio LC, Batchinsky Al. Bench-to-bedside optimization of mesenchymal stem cell isolation, processing, and expansion for in vivo administration. Regen Med. 2019;14(4):279-93.

16. Li H, Ghazanfari R, Zacharaki D, Lim HC, Scheding S. Isolation and characterization of primary bone marrow mesenchymal stromal cells. Ann N Y Acad Sci. 2016;1370(1):109-18.

17. Bourin P, Bunnell BA, Casteilla L, Dominici M, Katz AJ, March KL, Redl H, Rubin JP, Yoshimura K, Gimble JM. Stromal cells from the adipose tissuederived stromal vascular fraction and culture expanded adipose tissuederived stromal/stem cells: a joint statement of the International Federation for Adipose Therapeutics and Science (IFATS) and the International Society for Cellular Therapy (ISCT). Cytotherapy. 2013;15(6):641-8.

18. Rodriguez A-M, Elabd C, Amri E-Z, Ailhaud G, Dani C. The human adipose tissue is a source of multipotent stem cells. Biochimie. 2005;87(1):125-8.

19. Aust $L$, Devlin B, Foster $S$, Halvorsen $Y$, Hicok K, Laney $T$, Sen A, Willingmyre $\mathrm{G}$, Gimble J. Yield of human adipose-derived adult stem cells from liposuction aspirates. Cytotherapy. 2004;6(1):7-14.

20. Van Pham P, Vu NB, Phan NL-C, Le DM, Truong NC, Truong NH, Bui KH-T, Phan NK. Good manufacturing practice-compliant isolation and culture of human adipose-derived stem cells. Biomed Res Ther. 2014;1 (04):133-41.

21. Kassis I, Zangi L, Rivkin R, Levdansky L, Samuel S, Marx G, Gorodetsky R. Isolation of mesenchymal stem cells from G-CSF-mobilized human peripheral blood using fibrin microbeads. Bone Marrow Transplant. 2006; 37(10):967.

22. Fernández M, Minguell JJ. Human mesenchymal stem cells from peripheral blood. In: Google Patents; 2001.

23. Van Pham P, Vu NB, Pham VM, Truong NH, Pham TL-B, Dang LT-T, Nguyen T, Bui AN-T, Phan NK. Good manufacturing practice-compliant isolation and culture of human umbilical cord blood-derived mesenchymal stem cells. J Transl Med. 2014;12(1):56.

24. Lee OK, Kuo TK, Chen W-M, Lee K-D, Hsieh S-L, Chen T-H. Isolation of multipotent mesenchymal stem cells from umbilical cord blood. Blood. 2004;103(5):1669-75.

25. Van Pham P, Truong NC, Le PT-B, Tran TD-X, Vu NB, Bui KH-T, Phan NK. Isolation and proliferation of umbilical cord tissue derived mesenchymal stem cells for clinical applications. Cell Tissue Bank. 2016;17(2):289-302.

26. Kestendjieva S, Kyurkchiev D, Tsvetkova G, Mehandjiev T, Dimitrov A, Nikolov A, Kyurkchiev S. Characterization of mesenchymal stem cells isolated from the human umbilical cord. Cell Biol Int. 2008;32(7):724-32.

27. Ding D-C, Chang Y-H, Shyu W-C, Lin S-Z. Human umbilical cord mesenchymal stem cells: a new era for stem cell therapy. Cell Transplant. 2015;24(3):339-47

28. Le Blanc K, Ringden O. Immunomodulation by mesenchymal stem cells and clinical experience. J Intern Med. 2007;262(5):509-25.

29. Yagi H, Soto-Gutierrez A, Parekkadan B, Kitagawa Y, Tompkins RG, Kobayashi $\mathrm{N}$, Yarmush ML. Mesenchymal stem cells: mechanisms of immunomodulation and homing. Cell Transplant. 2010;19(6-7):667-79.

30. Kode JA, Mukherjee S, Joglekar MV, Hardikar AA. Mesenchymal stem cells: immunobiology and role in immunomodulation and tissue regeneration. Cytotherapy. 2009;11(4):377-91.

31. Abdi R, Fiorina P, Adra CN, Atkinson M, Sayegh MH. Immunomodulation by mesenchymal stem cells: a potential therapeutic strategy for type 1 diabetes. Diabetes. 2008;57(7):1759-67.

32. Fiorina P, Jurewicz M, Augello A, Vergani A, Dada S, La Rosa S, Selig M, Godwin J, Law K, Placidi C. Immunomodulatory function of bone marrowderived mesenchymal stem cells in experimental autoimmune type 1 diabetes. J Immunol. 2009;183(2):993-1004.

33. Zhang $R$, Liu Y, Yan $K$, Chen L, Chen X-R, Li P, Chen F-F, Jiang X-D. Antiinflammatory and immunomodulatory mechanisms of mesenchymal stem cell transplantation in experimental traumatic brain injury. J Neuroinflammation. 2013;10(1):871.

34. Kassis I, Grigoriadis N, Gowda-Kurkalli B, Mizrachi-Kol R, Ben-Hur T, Slavin S, Abramsky O, Karussis D. Neuroprotection and immunomodulation with mesenchymal stem cells in chronic experimental autoimmune encephalomyelitis. Arch Neurol. 2008;65(6):753-61.

35. Augello A, Tasso R, Negrini SM, Cancedda R, Pennesi G. Cell therapy using allogeneic bone marrow mesenchymal stem cells prevents tissue damage in collagen-induced arthritis. Arthritis Rheumatism. 2007:56(4):1175-86.

36. Vija L, Farge D, Gautier J-F, Vexiau P, Dumitrache C, Bourgarit A, Verrecchia F, Larghero J. Mesenchymal stem cells: stem cell therapy perspectives for type 1 diabetes. Diabetes Metab. 2009;35(2):85-93.

37. English K. Mechanisms of mesenchymal stromal cell immunomodulation. Immunol Cell Biol. 2013;91(1):19-26.

38. Nauta AJ, Fibbe WE. Immunomodulatory properties of mesenchymal stromal cells. Blood. 2007;110(10):3499-506.

39. Djouad F, Charbonnier LM, Bouffi C, Louis-Plence P, Bony C, Apparailly F, Cantos C, Jorgensen C, Noel D. Mesenchymal stem cells inhibit the differentiation of dendritic cells through an interleukin-6-dependent mechanism. Stem Cells. 2007;25(8):2025-32.

40. Singer NG, Caplan Al. Mesenchymal stem cells: mechanisms of inflammation. Annu Rev Pathol. 2011:6:457-78.

41. Ranganath SH, Levy O, Inamdar MS, Karp JM. Harnessing the mesenchymal stem cell secretome for the treatment of cardiovascular disease. Cell Stem Cell. 2012;10(3):244-58

42. Gnecchi M, Danieli P, Malpasso G, Ciuffreda MC. Paracrine mechanisms of mesenchymal stem cells in tissue repair. In: Mesenchymal Stem Cells: Springer; 2016. p. 123-46.

43. Paul G, Anisimov SV. The secretome of mesenchymal stem cells: potential implications for neuroregeneration. Biochimie. 2013;95(12): 2246-56.

44. Liang X, Ding Y, Zhang Y, Tse H-F, Lian Q. Paracrine mechanisms of mesenchymal stem cell-based therapy: current status and perspectives. Cell Transplant. 2014;23(9):1045-59. 
45. Liu ZJ, Zhuge Y, Velazquez OC. Trafficking and differentiation of mesenchymal stem cells. J Cell Biochem. 2009;106(6):984-91.

46. Kollar K, Cook MM, Atkinson K, Brooke G. Molecular mechanisms involved in mesenchymal stem cell migration to the site of acute myocardial infarction. Int J Cell Biol. 2009;2009:904682.

47. Wen Z, Zheng S, Zhou C, Wang J, Wang T. Repair mechanisms of bone marrow mesenchymal stem cells in myocardial infarction. J Cell Mol Med. 2011;15(5):1032-43.

48. Jacobs SA, Roobrouck VD, Verfaillie CM, Van Gool SW. Immunological characteristics of human mesenchymal stem cells and multipotent adult progenitor cells. Immunol Cell Biol. 2013;91(1):32-9.

49. Machado CV, PDdS T, ILO N. Immunological characteristics of mesenchymal stem cells. Rev Bras Hematol Hemoter. 2013;35(1):62-7.

50. Weiss DJ, Casaburi R, Flannery R, LeRoux-Williams M, Tashkin DP. A placebocontrolled, randomized trial of mesenchymal stem cells in COPD. Chest. 2013;143(6):1590-8.

51. Ribeiro-Paes JT, Bilaqui A, Greco OT, Ruiz MA, Marcelino MY, Stessuk T, de Faria CA, Lago MR. Unicentric study of cell therapy in chronic obstructive pulmonary disease/pulmonary emphysema. Int J Chron Obstruct Pulmon Dis. 2011;6:63.

52. Stessuk T, Ruiz MA, Greco OT, Bilaqui A, MJdO R-P, Ribeiro-Paes JT. Phase clinical trial of cell therapy in patients with advanced chronic obstructive pulmonary disease: follow-up of up to 3 years. Rev Bras Hematol Hemoter 2013;35(5):352-7.

53. Stolk J, Broekman W, Mauad T, Zwaginga J, Roelofs H, Fibbe W, Oostendorp J, Bajema I, Versteegh M, Taube C. A phase I study for intravenous autologous mesenchymal stromal cell administration to patients with severe emphysema. QJM. 2016;109(5):331-6.

54. François M, Copland IB, Yuan S, Romieu-Mourez R, Waller EK, Galipeau J. Cryopreserved mesenchymal stromal cells display impaired immunosuppressive properties as a result of heat-shock response and impaired interferon- $\gamma$ licensing. Cytotherapy. 2012;14(2):147-52.

55. Bonab MM, Alimoghaddam K, Talebian F, Ghaffari SH, Ghavamzadeh A, Nikbin B. Aging of mesenchymal stem cell in vitro. BMC Cell Biol. 2006;7(1): 14.

56. Beane OS, Fonseca VC, Cooper LL, Koren G, Darling EM. Impact of aging on the regenerative properties of bone marrow-, muscle-, and adipose-derived mesenchymal stem/stromal cells. PLoS One. 2014;9(12):e115963.

57. Ahmed ASI, Sheng MH, Wasnik S, Baylink DJ, Lau K-HW. Effect of aging on stem cells. World Jo Exp Med. 2017;7(1):1.

58. Bustos ML, Huleihel L, Kapetanaki MG, Lino-Cardenas CL, Mroz L, Ellis BM, McVerry BJ, Richards TJ, Kaminski N, Cerdenes N. Aging mesenchymal stem cells fail to protect because of impaired migration and antiinflammatory response. Am J Respir Crit Care Med. 2014;189(7):787-98.

59. Cheng H, Qiu L, Ma J, Zhang H, Cheng M, Li W, Zhao X, Liu K. Replicative senescence of human bone marrow and umbilical cord derived mesenchymal stem cells and their differentiation to adipocytes and osteoblasts. Mol Biol Rep. 2011;38(8):5161-8.

60. Van Pham P, Vu NB, Phan NK. Umbilical cord-derived stem cells (MODULATISTTM) show strong immunomodulation capacity compared to adipose tissue-derived or bone marrow-derived mesenchymal stem cells. Biomed Res Ther. 2016;3(06):687-96.

61. Li X, Bai J, Ji X, Li R, Xuan Y, Wang Y. Comprehensive characterization of four different populations of human mesenchymal stem cells as regards their immune properties, proliferation and differentiation. Int J Mol Med. 2014;34(3):695-704.

62. Wang $Q$, Yang $Q$, Wang Z, Tong H, Ma L, Zhang Y, Shan F, Meng Y, Yuan Z. Comparative analysis of human mesenchymal stem cells from fetal-bone marrow, adipose tissue, and Warton's jelly as sources of cell immunomodulatory therapy. Hum Vaccines Immunother. 2016;12(1):85-96.

63. Yu YB, Song Y, Chen Y, Zhang F, Qi FZ. Differentiation of umbilical cord mesenchymal stem cells into hepatocytes in comparison with bone marrow mesenchymal stem cells. Mol Med Rep. 2018;18(2):2009-16.

64. Wei X, Peng G, Zheng S, Wu X. Differentiation of umbilical cord mesenchymal stem cells into steroidogenic cells in comparison to bone marrow mesenchymal stem cells. Cell Prolif. 2012;45(2):101-10.

65. Wu L-F, Wang N-N, Liu Y-S, Wei X. Differentiation of Wharton's jelly primitive stromal cells into insulin-producing cells in comparison with bone marrow mesenchymal stem cells. Tissue Eng A. 2009;15(10):2865-73.

66. Shetty $P$, Thakur AM, Viswanathan C. Dopaminergic cells, derived from a high efficiency differentiation protocol from umbilical cord derived mesenchymal stem cells, alleviate symptoms in a Parkinson's disease rodent model. Cell Biol Int. 2013;37(2):167-80.

67. Phuc P, Ngoc V, Nhan P, Dung L, Nhat T, Nhung T, Khanh B, Ngoc P. Good manufacturing practice-compliant isolation and culture of human adiposederived stem cells. Biomed Res Ther. 2016;1 (04):133-41.

68. Ketterl N, Brachtl G, Schuh C, Bieback K, Schallmoser K, Reinisch A, Strunk D. A robust potency assay highlights significant donor variation of human mesenchymal stem/progenitor cell immune modulatory capacity and extended radio-resistance. Stem Cell Res Ther. 2015;6(1):236.

69. Le PT-B, Duong TM, Vu NB, Van Pham P. Umbilical cord derived stem cell (ModulatistTM) transplantation for severe chronic obstructive pulmonary disease: a report of two cases. Biomed Res Ther. 2016;3(10):902-9.

70. Deuse T, Stubbendorff M, Tang-Quan K, Phillips N, Kay MA, Eiermann T, Phan TT, Volk H-D, Reichenspurner H, Robbins RC. Immunogenicity and immunomodulatory properties of umbilical cord lining mesenchymal stem cells. Cell Transplant. 2011;20(5):655-67.

71. Wang M, Yuan Q, Xie L. Mesenchymal stem cell-based immunomodulation: properties and clinical application. Stem Cells Int. 2018;2018:3057624.

72. Yang ZX, Chi Y, Ji YR, Wang YW, Zhang J, Luo WF, Li LN, Hu CD, Zhuo GS, Wang LF. Human umbilical cord mesenchymal stem cells increase interleukin-9 production of CD4+ T cells. Exp Ther Med. 2017;14(4):3541-8.

73. Yang H, Sun J, Wang F, Li Y, Bi J, Qu T. Umbilical cord-derived mesenchymal stem cells reversed the suppressive deficiency of T regulatory cells from peripheral blood of patients with multiple sclerosis in a co-culture-a preliminary study. Oncotarget. 2016;7(45):72537.

74. Bartolucci J, Verdugo FJ, González PL, Larrea RE, Abarzua E, Goset C, Rojo P. Palma I, Lamich R, Pedreros PA. Safety and efficacy of the intravenous infusion of umbilical cord mesenchymal stem cells in patients with heart failure: a phase 1/2 randomized controlled trial (RIMECARD trial [randomized clinical trial of intravenous infusion umbilical cord mesenchymal stem cells on cardiopathy]). Circ Res. 2017;121(10):1192-204.

75. Kong D, Zhuang X, Wang D, Qu H, Jiang Y, Li X, Wu W, Xiao J, Liu X, Liu J. Umbilical cord mesenchymal stem cell transfusion ameliorated hyperglycemia in patients with type 2 diabetes mellitus. Clin Lab. 2014; 60(12):1969-76.

76. Li A, Tao Y, Kong D, Zhang N, Wang Y, Wang Z, Wang Y, Wang J, Xiao J, Jiang Y. Infusion of umbilical cord mesenchymal stem cells alleviates symptoms of ankylosing spondylitis. Exp Ther Med. 2017;14(2):1538-46.

77. Qin H, Zhu X, Zhang B, Zhou L, Wang W. Clinical evaluation of human umbilical cord mesenchymal stem cell transplantation after angioplasty for diabetic foot. Exp Clin Endocrinol Diabetes. 2016;124(08):497-503.

\section{Publisher's Note}

Springer Nature remains neutral with regard to jurisdictional claims in published maps and institutional affiliations.

Ready to submit your research? Choose BMC and benefit from:

- fast, convenient online submission

- thorough peer review by experienced researchers in your field

- rapid publication on acceptance

- support for research data, including large and complex data types

- gold Open Access which fosters wider collaboration and increased citations

- maximum visibility for your research: over $100 \mathrm{M}$ website views per year

At BMC, research is always in progress.

Learn more biomedcentral.com/submissions 